\title{
Recent claims of China's economic exceptionalism Reflections inspired by WTO accession
}

\author{
Wing Thye WOO \\ Economics Department, University of California, Davis, CA 95616 USA
}

\begin{abstract}
The desirability of WTO membership for China depends on whether its economic successes have been the result of its discovery of new institutional forms [e.g., dual-track pricing, state-owned enterprise (SOE) contracts, and fiscal contracts] that are optimal for China's particular economic circumstances or have been the result of the convergence of its economic institutions to those of a typical advanced member of WTO. If the experimentalist interpretation of China's phenomenal growth is correct, then WTO membership is a negative development because it could be a straitjacket for WTO-enforced institutional harmonization that would constrain China's scope for experimentation. But, if the experimentalist interpretation is wrong, then WTO membership is a positive development that will lock China on to the path of deepening economic reform. We assess several recent claims of China's economic exceptionalism and conclude that they neglected the considerable costs associated with the use of these innovative mechanisms (which have led to the repeal of every one of these "optimal" mechanisms) and that these mechanisms were unlikely to have produced positive results in the transition economies in Europe. Because a major reason for the failure of Gorbachev's reforms was opposition from the entrenched interests within the ruling structure, China's forthcoming WTO accession could be seen as an attempt by reformers to lock economic policies on to a market-oriented course that is costly to reverse. (C) 2001 Elsevier Science Inc. All rights reserved.
\end{abstract}

Keywords: Economics of transition; WTO; Economic reform in China; Dual-track pricing; State enterprise reform; Privatization; Fiscal system; Convergence school; Experimentalist school

E-mail address: wtwoo@ucdavis.edu (W.T. Woo).

1043-951X/01/\$ - see front matter (C) 2001 Elsevier Science Inc. All rights reserved. PII: S 1 043-951X(0 1)00047-5 


\section{Introduction}

The phenomenal growth of China in the last two decades is not in much dispute. What has been the subject of vigorous research and of even more vigorous debate are the causes of this phenomenal growth. While there is broad agreement that the most important part of the answer is the marketization of the economy and its integration into the international division of labor, there is much less agreement over the relative contributions of the many economic mechanisms that were put into motion by these two policies. For example, while virtually all economists would agree with the proposition that complete price flexibility is to be preferred over complete price fixity, there can be disagreement over the optimal speed at which price flexibility is to be introduced and the economic mechanism through which a given speed is to be implemented.

Suppose that even if agreement could be reached, $20 \%$ of prices are to be decontrolled in each of the first 2 years instead of $5 \%$ or $50 \%$ each year. There still remains the choice of totally freeing the prices of $20 \%$ of the commodities or of allowing $20 \%$ of each commodity to be sold at freely determined prices. In this case, there is agreement over the general principle of price flexibility but not necessarily over the implementation of this principle.

Of course, there is then the more difficult issue of whether the same economic mechanism can be applied successfully across different economic sectors. This is clearly the case in the use of the "contract responsibility system" (CRS) to implement the principle of decentralized decision-making. Many researchers will agree that the household responsibility system unleashed sustained productivity improvements in the agricultural sector that boosted economic growth substantially, especially in the 1978-1984 period. But, many fewer researchers can agree that the enterprise responsibility system generated impressive productivity gains in the state enterprise sector that lifted the overall growth rate significantly, even in the 1984-1988 period. Clearly, the difference in outcomes could be due to a combination of the differences in the way that CRS was implemented in each sector and in the structure of agricultural and industrial production. While descriptive differences are obvious and many on the implementation front and on the structural front, our priors are that the production relationships in agriculture and industry are so different that there is a different optimal economic mechanism for implementing the "decentralized decision-making" principle in each sector.

The difference in sectoral outcomes to the CRS mechanism raises many intriguing but disturbing hypotheses. Possibly the most relevant of these hypotheses for China on the eve of its WTO accession is whether the optimal economic mechanism for a particular sector in a foreign country can also be the optimal, or even a useful, economic mechanism for the same sector in China. Specifically, is it possible that while (almost) complete marketization and total internationalization of economic activities were optimal for the capitalist East Asian economies, they would be disastrous for China's economy? Is this the reason for the vastly different output responses of China in 1979 and of Poland in 1990 when they embarked on their market-oriented reform paths? More specifically, what are the optimal degree of marketization and the optimal degree of international integration for each country? In light of China's high growth since 1978, is China already at, or already close to, the optimal degree 
on these two fronts such that entry into WTO and the harmonization of Chinese economic institutions to WTO-specified institutional forms will cause an overshooting of marketization and internationalization fronts?

The aim of this paper is to argue that China is still below the optimal degree of marketization and international integration and that the chosen method of WTO membership to advance marketization and integration is a desirable one, conditional upon supplementary policies being enacted to reduce the adjustment costs. In our view, even with WTO membership, China stands a much greater chance of undershooting on both fronts than of overshooting. Our case for China's WTO membership is based on the proposition that China's economic progress since 1978 has been the result of China's institutional convergence to a prototype WTO market economy rather than the result of China's economic institutions being different from those of a prototype WTO economy. We will make our case by examining some claims in the literature of Chinese economic exceptionalism as being the cause of the phenomenal growth.

It is important to state at the outset that we agree with some important parts in these claims of Chinese economic exceptionalism. While we recognize that China has had the luxury of more than one feasible path to a prototype WTO market economy, we see that the costs and unsustainability of some of these alternative feasible paths have not been adequately laid out. Furthermore, while we also recognize that the prototype WTO market economy accommodates a variety of institutional forms, we hold that there are some key features of a prototype WTO economy that are important for China to converge to. These key institutional features include near absence of state intervention in price setting, dominance of private ownership, primary reliance on capital markets to allocate investment capital, and overwhelming evenhandedness in legal treatment of state capital, domestic private capital, and foreign capital. China has almost achieved the first feature, has made some big strides since 1993 on the second, and is still largely amiss on the third and fourth.

Before starting the discussion, we would like to say a few words about the obfuscating terminology that the debate over transition strategies has generated. A wealth of oxymora has been conjured up because protagonists have sought to attach undeserved positive connotations to their viewpoints. A number of authors have labeled rapid, comprehensive reforms (big bang reforms) as top-down reforms and slow, partial reforms (incremental reforms) as bottom-up reform. Big bang reforms were hence associated with a reform style that is reminiscent of central planning coercion and incremental reforms with a democratic trial-anderror market-learning process. These two associations are largely false and self-contradictory as suggested by the following two considerations.

First, the reliance on markets to allocate resources represents decentralized economic management achieved by empowering individual initiatives. Markets are naturally occurring phenomenon because they render both buyers and sellers better off. The only time when markets are absent is when they are suppressed by the central plan of the state. Marketization means allowing the bottom-up process to run its natural course. Second, reform of a centrally planned economy means the marketization of economic transactions and the deep entrenchment of market-supporting institutions such as the criminal justice system to maintain law and order, commercial courts to enforce contracts, bankruptcy 
courts to encourage prudent lending and enable fresh starts for entrepreneurs, and social safety nets to lower the costs of resource reallocation. By its nature, marketization can be accomplished quickly if desired, but the firm entrenchment of market-supporting institutions cannot be achieved quickly even if desired.

In short, big bang reforms (quick marketization) means the unleashing of the bottom-up process of individual initiatives on a grand scale, while incremental reforms (slow marketization) means incremental legalization of the bottom-up process. The amazing semantic sleight of hand that has happened is that the advocates of gradual reform have identified themselves as advocates of the bottom-up approach to economic management! It is time for the misleading terms of "top-down reform" and "bottom-up reform" to be dropped from the transition strategy debate.

The two words "evolutionary" and "path-dependent" are often encountered in the transition literature, and while they are always accurate, they are not always useful. In the strictest sense, rational policymaking is evolutionary and path-dependent by necessity. Policymaking has to be evolutionary because new exogenous shocks are always appearing, and it is nearly always path-dependent because reversals can be expensive, if not impossible. For example, China's tariff policy is contingent on whether China is already a WTO member or not.

There is one important sense in which the term "evolutionary" is analytically useful. Take the case of bankruptcy procedures. They were not needed during the planning period, and so they were nonexistent prior to 1990 . With the transition to a market economy, the state faces two policy choices. The first policy is to adopt the bankruptcy procedures of another country after modifying them to accommodate relevant differences in national circumstances and then to continue to modify them in light of experience. The second policy is to rely on the bottomup process in the most fundamental sense by encouraging its citizens to come up with private contractual arrangements that would cover the contingency of financial difficulties that the borrowers might encounter. Comparing these two policies, we see that the first promotes institutional evolution in the local sense, and the second choice promotes institutional evolution in the global sense.

In practice, institutional evolution in the local sense entails a proactive state in the sphere of institution building where the usual operational principle is to adopt a foreign prototype and then modify it through practice. ${ }^{1}$ Institutional evolution in the global sense, on the other hand, requires a state that is agnostic and passive about institution building because of its unbridled faith that the demand for institutions will inevitably induce the appropriate institutional innovations. Sachs and Woo (2000) called the first approach "the convergence school of institution building" and the second approach the "experimentalist school of institution building."

The misunderstanding over these two approaches to institution building has caused the biggest obfuscation in the debate over transition strategies for China. The transition debate

\footnotetext{
${ }^{1}$ The earliest country in the industrial age to implement this operational principle successfully and hence attain first world status is Japan.
} 
for China has primarily been a debate over the origins of institutions and the desired direction for institutional evolution and only very secondarily been a debate over the speed of implementing the reform program, even though the debate did focus on speed in the beginning. The real question in the transition debate on China still remains whether a third way exists between socialist planning and capitalist markets.

In sharp contrast, the fundamental academic issue in the postmortem debate on transition strategies for Eastern Europe and the former Soviet Union (EEFSU) is the desired speed for institutional changes because leading EEFSU economists (such as Kornai, 1992) take it for granted that there is no third way. There is clearly no simple answer to the speed issue because "the transition from socialism to capitalism ... is a curious amalgam of revolution and evolution." Some reforms, such as macroeconomic stabilization, have to be done very quickly, and some reforms, such as privatization, have to be done much slower. Also, in all cases, the decision on speed has to take into account the administrative capacity of the state and the political situation in the country.

It is clear that most of EEFSU have embraced the convergence school of institution building (albeit with different speeds in implementation), but would it be accurate to say that China has followed the experimentalist school of institution building, since many of the critics of quick marketization have explained the gradual pace of Chinese reform as being due to the time-consuming process of experimentation to discover policies and institutions that are optimal for China's economic situation? If the experimentalist interpretation of China's phenomenal growth is correct, then China's forthcoming WTO membership is a negative development because it could be a straitjacket that would constrain China's scope for experimentation. But, if the experimentalist interpretation is wrong, then WTO membership is a positive development that will lock China on to the path of deepening economic reform and openness.

Sachs and Woo (2000) presented a comprehensive survey of China's performance up to 1994 and concluded that China's phenomenal growth had come from its convergence to a prototype WTO economy. Therefore, another objective of this paper is to assess several recent interesting additions to the literature to see whether the Sachs and Woo's conclusion still holds and, hence, whether optimism about China's WTO accession is still justified.

\section{The feasibility and optimality of the dual-track reform strategy}

Strictly speaking, "dual track" does not capture the complexity of China's reform policies. In different periods, there was dual track for the pricing of inputs, output, and foreign exchange; five tracks for ownership in the service and light industrial sectors (individual, state, collective, private, and foreign); multiple track for revenue sharing between the center and the provinces (Guangdong and Fujian signed lump sum revenue contracts with a 5-year duration, and the other provinces paid varying proportions of their revenue to the center);

\footnotetext{
${ }^{2}$ Kornai (2000, p. 25).
} 


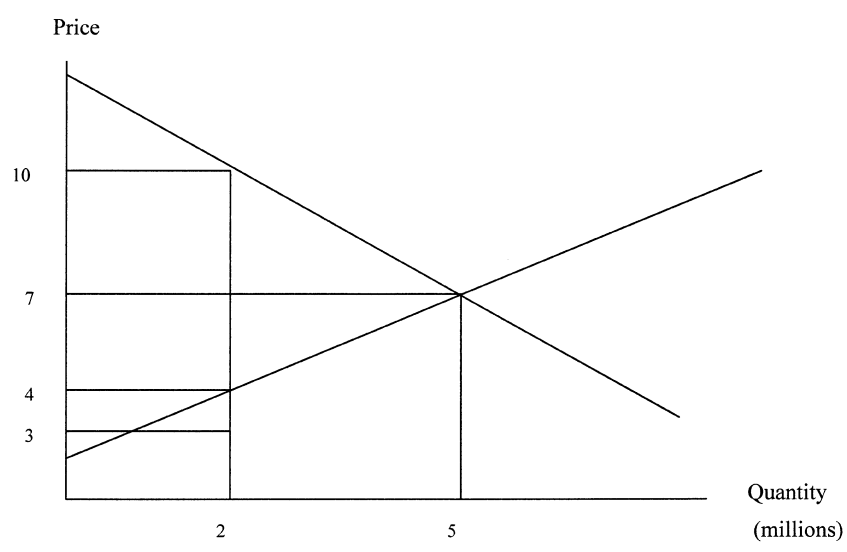

Fig. 1. The light industrial goods market.

multitrack for international trade and foreign direct investments (with Shenzhen having the most liberal regime for the longest time); and a single track, until recently, for interest rates and ownership in the banking sector.

In this section, we will focus mainly on the dual-track price reform. ${ }^{3}$ The academic analysis of China's dual-track price system (DTPS) has gone through two phases: the partial equilibrium approach and the general equilibrium approach. Proponents of the DTPS describe it as a Pareto-improving way of introducing price flexibility that encourages growth without arousing political opposition from entrenched interest groups. We find this claim of gainwithout-pain to be either factually wrong or politically implausible.

\subsection{The partial equilibrium analysis (PEA) of dual-track pricing}

The analytics can be summarized by the following example when there is a light industrial good and a heavy industrial good, with the following supply and demand relationships in a free market setting. For the light industrial good, we assume

$$
\begin{array}{ll}
\text { Supply curve (marginal cost curve): } & P=2+Q \\
\text { Demand curve: } & P=12-Q \text { where } Q \text { is in units of millions. }
\end{array}
$$

For the heavy industrial good, we assume

$$
\begin{array}{ll}
\text { Supply curve (marginal cost curve): } & P=3+2 Q \\
\text { Demand curve: } & P=12-Q \text { where } Q \text { is in units of millions. }
\end{array}
$$

Under the free market in the light industrial good market: $P=7$ and $Q=5$; and in the heavy industrial good market: $P=9$ and $Q=3$ (see Figs. 1 and 2).

\footnotetext{
3 This part draws upon Woo (2000).
} 


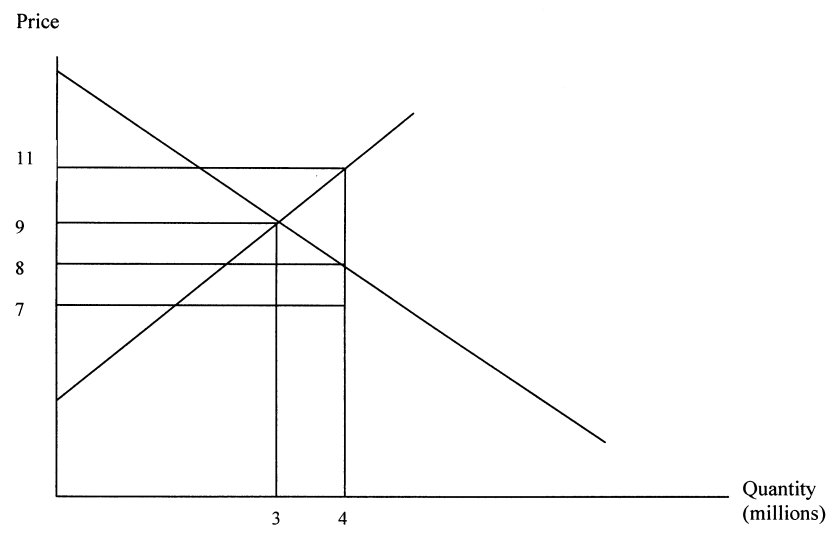

Fig. 2. The heavy industrial goods market.

For the central plan situation, assume the modus operandi to be where the planner picks the output level in each industry and sets the plan price to equate revenue with production costs of the output quota. Furthermore, assume that the planner creates the typical Stalinist outcome where the light industrial good is underproduced vis-a-vis the free market situation, and the heavy industrial good is overproduced vis-a-vis the free market situation. ${ }^{4}$

Say, for light industrial goods, the planner picks $Q=2$ and hence sets $P=3$. The result is a black market price of 10 with the marginal cost being 4 . Also, say, for heavy industrial goods, the planner picks $Q=4$ and hence sets $P=7$. The result is a black market price of 8 with the marginal cost of 11 .

DTPS is the situation where the producer is allowed to sell his above-quota output at a freely determined price. Then, for the light industrial good, we have: market price $=7$; market quantity $=3$; plan price $=3$; plan quantity $=2$.

The total quantity of 5 represents an increase in the output of the light industrial good, with no decrease in quantities sold at the lower plan price to the privileged buyers. This is a Paretoimproving situation.

For the heavy industrial good, we have: market price $=8$; market quantity $=0$ because the marginal cost exceeds the market price; plan price $=7$; plan quantity $=4$.

The total quantity produced remains at 4 with no losers and no winners. So, the overall situation from the DTPS is a Pareto-improving situation.

Complete price liberalization (big bang reform), as is clear from Figs. 1 and 2, is not Paretoimproving because the privileged buyers of both goods under rationing will now have to pay higher prices. There will be laid-off workers in the heavy industrial goods sector. A big bang will cause a collapse in the production of heavy industrial goods, and the resulting disorganization (a la Blanchard \& Kremer, 1997) could cause a temporary drop in the

\footnotetext{
${ }^{4}$ As will be documented later, in 1988, the Soviet Union produced 15 times more crude steel per dollar of GDP than the US and eight times more than West Germany and Japan. The Soviet Union also produced five times more refined copper per dollar of GDP than the US, West Germany, and Japan.
} 
production of light industrial goods as well, a situation that is reminiscent of Poland and Russia upon the marketization of their economies in January 1990 and January 1992, respectively.

The key lesson from the PEA is that partial price flexibility is superior to total price flexibility.

\subsection{The general equilibrium analysis (GEA) of dual-track pricing}

The inadequacy of PEA is obvious if these two goods comprise the entire production structure and if there were full employment and maximum production efficiency under the original central planning situation. In this context, the introduction of dual-track pricing cannot cause an increase in the output of the light industrial good unless there is a decrease in the output of the heavy industrial good, and how could the occurrence of the latter still make the DTPS Pareto-improving?

Lau, Qian, and Roland (2000) answered this question by claiming that the light industrial good supplier will execute the following sequence of actions:

(a) Go into the market for the heavy industrial good and buy (at the free market price) the rights to some of the planned output that was allocated to privileged consumers (at the free market price). Say that he bought the rights to $X$ units of the heavy industrial good.

(b) Tell the heavy industrial good producer to reduce his production by $X$ units and send the released workers to work in the light industrial good sector

(c) Hire the newly released workers from the heavy industrial sector and expand the production of the light industrial good by $Y$ units.

The heavy industrial good producer is happy to cooperate because he now makes a positive profit from his costs having decreased more than his revenue. One of the possible outcomes is that $X=1$ and $Y=3$, which makes the dual-tracking outcome the same as the free market outcome. The important prediction is that the DTPS, in a general equilibrium setting, will cause one sector to expand and the other sector to shrink as in complete price liberalization, and this DTPS-induced adjustment is contractual and mutually beneficial in nature.

For policy purposes, both PEA and GEA offer the same advice: limited price deregulation is better than complete price deregulation. Complete price deregulation might produce the same input allocation and output composition as the DTPS, but the former definitely generates resentment against the government while the latter does not.

\subsection{Critique of the preceding two analyses of the DTPS}

It is ironic that the supposedly flawed PEA is factually more correct than the theoretically coherent GEA. Table 1 shows that the output of both the light and heavy industrial sectors went up every year following the introduction of the DTPS in 1985.5 Light industrial output increased $64 \%$ in the $1984-1987$ period and heavy industrial output

${ }^{5}$ The rise of the light industrial component of the industrial sector from $39 \%$ of total industrial output in 1978 to $48 \%$ in 1988 and $51 \%$ in 1998 reflected, in part, its suppression under central planning. 
Table 1

Production of light and heavy industrial goods and state sector employment, 1978-1998

\begin{tabular}{|c|c|c|c|c|c|c|}
\hline & \multicolumn{2}{|c|}{$\begin{array}{l}\text { Index of } \\
\text { gross industrial } \\
\text { output, } 1978=100\end{array}$} & \multicolumn{2}{|c|}{$\begin{array}{l}\text { Composition of gross } \\
\text { industrial output } \\
\text { in } 1995 \text { prices (\%) } \\
\end{array}$} & \multirow{2}{*}{$\begin{array}{l}\text { Proportion of } \\
\text { labor force in } \\
\text { state-owned } \\
\text { units }(\%)\end{array}$} & \multirow{2}{*}{$\begin{array}{l}\text { Proportion of } \\
\text { gross industrial } \\
\text { production by } \\
\text { state-owned units, } \\
\text { current prices }(\%)\end{array}$} \\
\hline & $\begin{array}{l}\text { Light } \\
\text { industry }\end{array}$ & $\begin{array}{l}\text { Heavy } \\
\text { industry }\end{array}$ & $\begin{array}{l}\text { Light } \\
\text { industry }\end{array}$ & $\begin{array}{l}\text { Heavy } \\
\text { industry }\end{array}$ & & \\
\hline 1978 & 100.0 & 100.0 & 38.9 & 61.1 & 18.6 & 77.6 \\
\hline 1979 & 110.0 & 108.0 & 39.3 & 60.7 & 18.8 & 78.5 \\
\hline 1980 & 130.8 & 110.1 & 43.1 & 56.9 & 18.9 & 76.0 \\
\hline 1981 & 149.5 & 105.1 & 47.5 & 52.5 & 19.1 & 74.8 \\
\hline 1982 & 158.2 & 115.5 & 46.6 & 53.4 & 19.1 & 74.4 \\
\hline 1983 & 172.9 & 130.6 & 45.7 & 54.3 & 18.9 & 73.4 \\
\hline 1984 & 200.7 & 152.2 & 45.6 & 54.4 & 17.9 & 69.1 \\
\hline 1985 & 246.3 & 182.9 & 46.1 & 53.9 & 18.0 & 64.9 \\
\hline 1986 & 278.5 & 201.6 & 46.8 & 53.2 & 18.2 & 62.3 \\
\hline 1987 & 330.3 & 235.3 & 47.2 & 52.8 & 18.3 & 59.7 \\
\hline 1988 & 403.3 & 280.9 & 47.7 & 52.3 & 18.4 & 56.8 \\
\hline 1989 & 436.4 & 305.9 & 47.6 & 52.4 & 18.3 & 56.1 \\
\hline 1990 & 476.6 & 324.9 & 48.3 & 51.7 & 16.2 & 54.6 \\
\hline 1991 & 548.0 & 372.0 & 48.4 & 51.6 & 16.5 & 56.2 \\
\hline 1992 & 657.7 & 479.8 & 46.6 & 53.4 & 16.6 & 51.5 \\
\hline 1993 & 835.2 & 611.8 & 46.5 & 53.5 & 16.5 & 57.3 \\
\hline 1994 & 1032.3 & 762.3 & 46.3 & 53.7 & 16.2 & 37.3 \\
\hline 1995 & 1268.7 & 899.5 & 47.3 & 52.7 & 16.1 & 34.0 \\
\hline 1996 & 1573.2 & 1013.7 & 49.7 & 50.3 & 15.9 & 36.3 \\
\hline 1997 & 1801.3 & 1132.4 & 50.3 & 49.7 & 15.5 & 31.6 \\
\hline 1998 & 2013.9 & 1242.2 & 50.8 & 49.2 & 12.6 & 28.2 \\
\hline
\end{tabular}

Data calculated from State Statistical Bureau of China (1999).

increased 55\%. Lau et al.'s prediction of a (voluntary) contraction in heavy industrial output upon marketization of the economy is contradicted by the data, suggesting that their elaborate GEA could be an exercise in false precision. Clearly, we need an explanation other than the DTPS to explain why China grew so fast upon marketization.

Table 1 shows two interesting facts that suggest an alternative explanation for what really happened in China. First, output from industrial SOEs increased every year in the reform era, but the state sector's share of total industrial output declined secularly from $78 \%$ in 1978 to $28 \%$ in 1998. This means that the bulk of the increase in industrial output came from the nonstate sector. Hence, fast growth of industrial output should not be attributed entirely to the incentive effect of dual-track pricing. Most of the credit, in our judgement, should be given to the legalization of the dual-track ownership system in the industrial sector in 1984. The legalization of nonstate firms allowed nonstate industrial enterprises to be established in the rural areas, the famous township, and village enterprises (TVE).

Second, the nonstate sector did not grow by obtaining their labor from the state sector through contractual agreements, the key mechanism behind the Lau et al.'s assertion of "gain without pain." State employment was $17.9 \%$ of the labor force in 1984 (the eve of the 
Table 2

Production in employment structure in China, Soviet Union, and US

Part A: China: change in production and employment, 1978-1998

\begin{tabular}{llllllll}
\hline & \multicolumn{2}{l}{ Composition of GDP, 1995 prices $(\%)$} & & \multicolumn{3}{c}{ Composition of employment $(\%)$} \\
\cline { 2 - 3 } & Primary & Secondary & Tertiary & & Primary & Secondary & Tertiary \\
\hline 1978 & 41.2 & 34.0 & 24.7 & & 70.5 & 17.3 & 12.2 \\
1979 & 40.9 & 34.2 & 24.9 & & 69.8 & 17.6 & 12.6 \\
1980 & 38.0 & 37.0 & 24.9 & & 68.7 & 18.2 & 13.1 \\
1981 & 38.4 & 35.6 & 26.0 & & 68.1 & 18.3 & 13.6 \\
1982 & 39.0 & 34.2 & 26.7 & & 68.1 & 18.4 & 13.4 \\
1983 & 38.1 & 34.2 & 27.8 & & 67.1 & 18.7 & 14.2 \\
1984 & 37.3 & 33.9 & 28.8 & & 64.0 & 19.9 & 16.1 \\
1985 & 33.8 & 35.9 & 30.3 & & 62.4 & 20.8 & 16.8 \\
1986 & 32.2 & 36.5 & 31.3 & & 60.9 & 21.9 & 17.2 \\
1987 & 30.3 & 37.5 & 32.2 & & 60.0 & 22.2 & 17.8 \\
1988 & 28.2 & 38.8 & 33.0 & & 59.4 & 22.4 & 18.3 \\
1989 & 28.0 & 38.4 & 33.6 & & 60.0 & 21.6 & 18.3 \\
1990 & 28.9 & 38.0 & 33.0 & & 60.1 & 21.4 & 18.5 \\
1991 & 27.2 & 39.7 & 33.0 & & 59.7 & 21.4 & 18.9 \\
1992 & 25.1 & 42.3 & 32.6 & & 58.5 & 21.7 & 19.8 \\
1993 & 23.2 & 44.8 & 31.9 & & 56.4 & 22.4 & 21.2 \\
1994 & 21.5 & 47.3 & 31.2 & & 54.3 & 22.7 & 23.0 \\
1995 & 20.5 & 48.8 & 30.7 & & 52.2 & 23.0 & 24.8 \\
1996 & 19.7 & 50.0 & 30.3 & & 50.5 & 23.5 & 26.0 \\
1997 & 18.8 & 50.7 & 30.5 & 49.9 & 23.7 & 26.4 \\
1998 & 18.1 & 51.5 & 30.4 & 49.8 & 23.5 & 26.7
\end{tabular}

Part B: cross-country comparison of production and employment structure

\begin{tabular}{|c|c|c|c|c|c|c|}
\hline & \multicolumn{3}{|c|}{ Composition of GDP, 1995 prices (\%) } & \multicolumn{3}{|c|}{ Composition of employment (\%) } \\
\hline & US, 1986 & $\begin{array}{l}\text { Soviet } \\
\text { Union, } 1988\end{array}$ & China, 1978 & US, 1986 & $\begin{array}{l}\text { Soviet } \\
\text { Union, } 1988\end{array}$ & China, 1978 \\
\hline Agriculture & 1.9 & 9.3 & 41.2 & 2.7 & 19.3 & 70.5 \\
\hline Industry & 23.5 & 48.9 & 28.9 & 17.6 & 28.9 & $17.3^{\mathrm{a}}$ \\
\hline Construction & 6.1 & 10.7 & 5.1 & 4.6 & 11.5 & $\mathrm{~b}$ \\
\hline Services & 68.5 & 31.1 & 24.7 & 75.1 & 40.3 & 12.2 \\
\hline
\end{tabular}

China data from State Statistical Bureau of China (1999). Statistics for US and Soviet Union are from Lipton and Sachs (1992).

${ }^{a}$ Data include construction.

${ }^{\mathrm{b}}$ Data included in industry category.

introduction of the DTPS to the industrial sector) and it rose to $18.3 \%$ in 1989 (the eve of the replacement of the DTPS with almost complete price decontrol). The state sector in 1989 employed 14.7 million workers more than in 1984 and 26.6 million more than in 1978. In employment terms, China was certainly not growing out of the plan either in absolute or in relative terms. ${ }^{6}$

\footnotetext{
${ }^{6}$ State employment was 109.5 million in 1996 compared to 74.5 million in 1978.
} 
The labor that fuelled the fast expansion of the nonstate industrial sector came out from agriculture, a sector that was not identified by Lau et al. as an important contributor to China's high growth rates after 1984. Part A of Table 2 shows that employment in the primary sector declined from $71 \%$ in 1978 to $50 \%$ in $1998 .^{7}$ Therein, we have the deus ex machina of China's growth. The marketization and internationalization of economic activities generated substantial productivity increases not only by enlivening the agricultural sector in the 19791984 period and by creating a dynamic nonstate sector from 1984 onward but also by moving low-productivity agricultural workers into higher-productivity jobs in the secondary and tertiary sectors. ${ }^{8}$ In short, China's marketization and internationalization policies initiated the nonzero sum process of economic development, moving China away from a subsistence peasant economy and causing agriculture to drop from 41\% of GDP in 1978 to $18 \%$ in 1998 .

Part B of Table 2 explains why Russia's GDP fell upon marketization of its economy. The Russian industrial sector, especially the heavy industrial component, ${ }^{9}$ was much bigger than what a market economy would require. Industrial output accounted for $49 \%$ of Russia's GDP in 1988 compared to $24 \%$ of US GDP in 1986 . Given the relatively small proportion of labor in Russian agriculture compared to China (19\% vs. $71 \%$ ), a substantial amount of the labor needed for the growth of new light industries and new service activities had to come from the heavy industrial sector. The collapse of Russia's heavy industries was necessary in order to release the labor placed there by the central plan. ${ }^{10}$ The salient point is that the marketization of the overindustrialised Russian economy triggered the almost-zero sum (certainly so, in the short run) process of economic restructuring.

The importance of how existing structural conditions shape the output response to marketization is captured in Fig. 3, which shows a three-dimensional production possibility frontier of output from agriculture, light industry and services, and heavy industry. Point B on plane NOP denotes the production mix of a developed private market economy that is integrated into the international division of labor. Point $\mathrm{A}$, which is also on plane NOP, represents Russia on the eve of its marketization in 1992, and Point C on plane KLM represents China in 1978. The difference between plane NOP and plane KLM

\footnotetext{
${ }^{7}$ This decline in agricultural employment is likely to be understated because it does not take illegal migration into account.

${ }^{8}$ Woo (1998) estimated that the reallocation of Chinese agricultural labor into industries and services added 1.3 percentage points annually to the GDP growth rate over the 1985-1993 period.

9 This point is very well seen in the production of the following metals expressed in thousands of metric tons per US billion dollars of GDP for the following countries in 1988 (from Lipton \& Sachs, 1992):

Crude steel

Refined copper

Primary aluminum

$\begin{array}{cc}\text { Soviet Union } & \text { US } \\ 280.0 & 18.49 \\ 1.71 & 0.38 \\ 4.28 & 0.80\end{array}$

West Germany

0.36

0.62

Japan 36.47

0.01

${ }^{10}$ Sachs and Woo (1994) pointed out that there had to be a big cut in welfare subsidies provided by the government through the state enterprises before workers could be induced to seek employment in the new nonsubsidized private sector.
} 


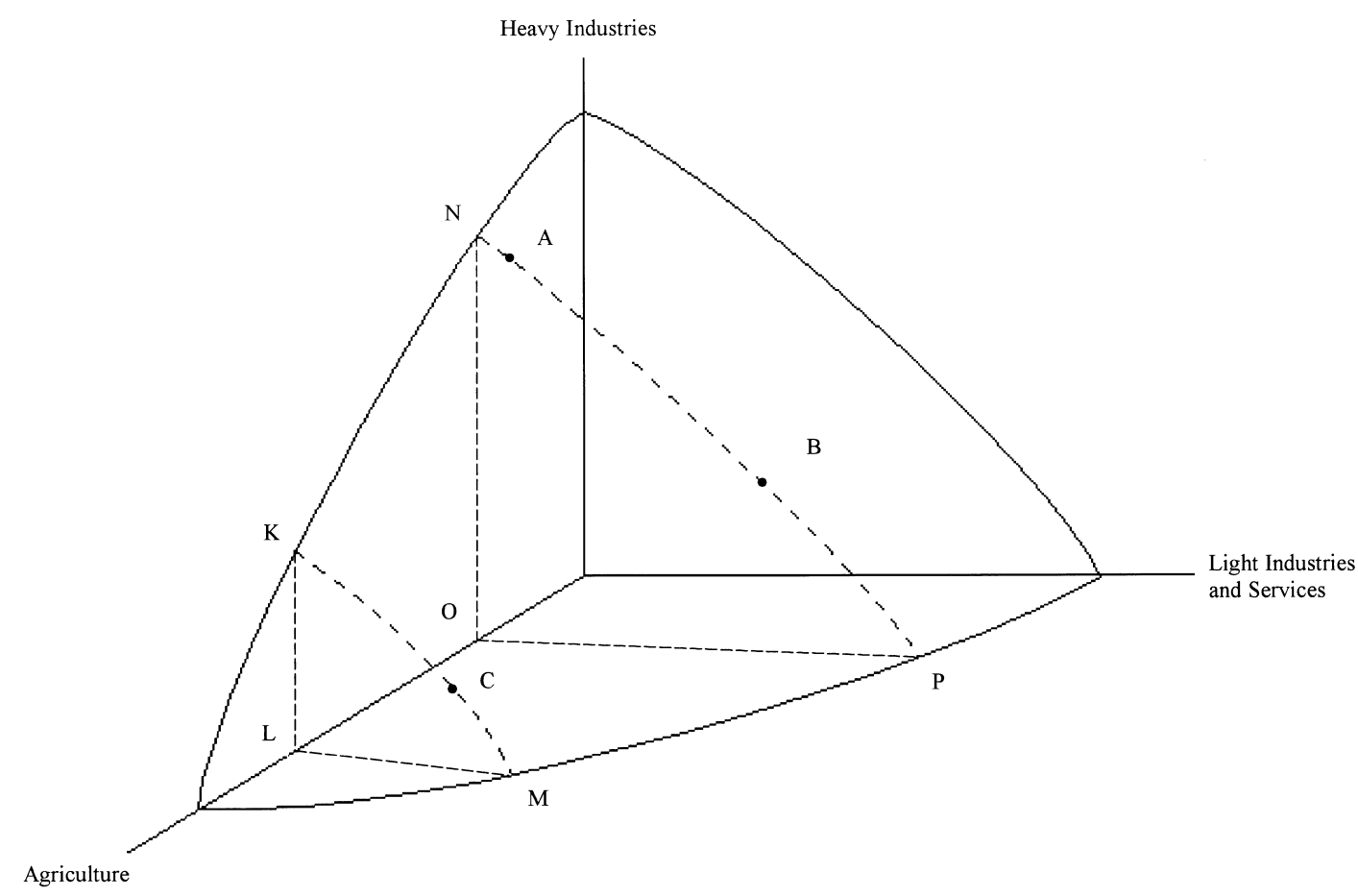

Fig. 3. Russia versus China: industrialized economy versus agricultural economy.

is that the former represents economies that are more advanced in their industrialisation and urbanisation.

In Fig. 4, we show in a heuristic picture of that the movement from $\mathrm{C}$ to $\mathrm{B}$ is likely to be a less painful process than the movement from A to B. We project the KLM plane onto the NOP plane to produce the $\mathrm{K}^{\prime} \mathrm{OM}^{\prime}$ plane, with $\mathrm{C}^{\prime}$ being the projection of $\mathrm{C}$. Within the context of the NOP plane, the movement from $\mathrm{C}^{\prime}$ to $\mathrm{B}$ is Pareto-improving, while the movement from A to B involves the shrinking of the industrial sector. More generally, the movement from $\mathrm{C}$ to $\mathrm{B}$ is Pareto-improving because the marginal value product of labor (MVPL) is lowest in agriculture. Chow (1993) found the marginal value product of labor in China in 1978, measured in 1952 prices, to be 63 yuan in agriculture, 1027 yuan in industry, 452 yuan in construction, 739 yuan in transportation, and 1809 yuan in commerce. This is the true source of the Pareto-improving outcome in China's economic reform and not the dual-pricing system.

\subsection{An important but ignored cost of the DTPS}

One of the biggest claims of virtue for the DTPS is that by avoiding the creation of losers, it does not generate political opposition to economic reform (except, of course, from central planning ideologues). We find such a claim to be dubious because dual-track pricing creates opportunities for corruption, and serious corruption can undermine the political legitimacy of 


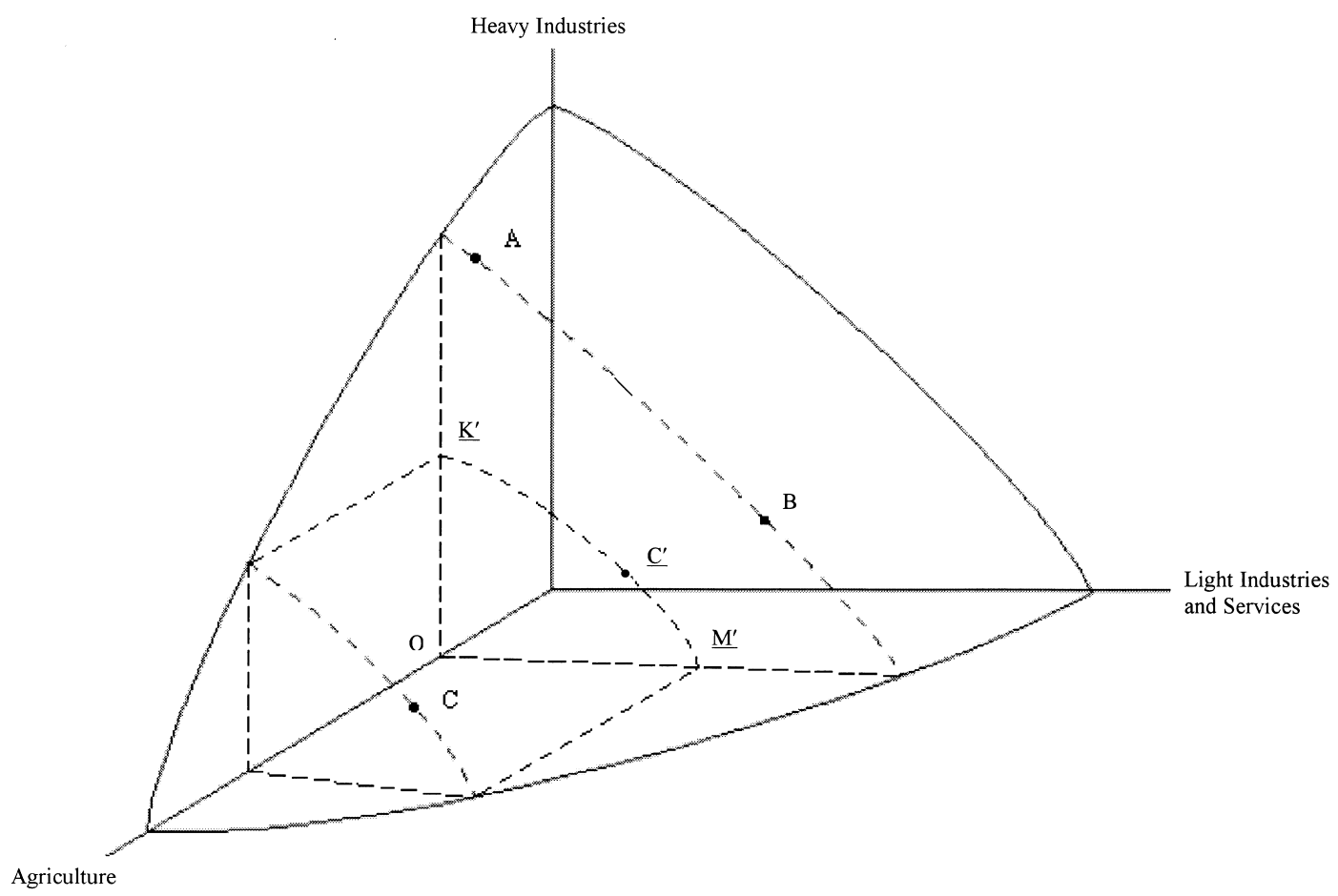

Fig. 4. Comparing Russia and China in a two-dimensional framework.

the government, if not also, the political stability of the country. In our understanding of the history of Chinese reforms, the DTPS was an unsustainable economic mechanism not only from the management viewpoint of extreme difficulties in administration but also from the political viewpoint of maintaining the cohesion of the ruling coalition.

To see this point, it is important to first note that the DTPS was only one component of the serious attempt (beginning in 1984) to improve the rationality of the SOE system, and the other component was the devolution of decision-making power to the SOEs. The political cost of the DTPS, as we will point out, came from its interaction with the operational autonomy of the SOEs in an unexpected way.

The plan track for inputs conferred instant profits upon the favored purchaser upon reselling quota inputs in the free market. Many children of top leaders were able to make purchases of inputs at plan prices and resell them at large profits. The general public was not happy with this widespread corrupt practice. The devolution of operational autonomy to SOEs in a soft budget situation caused demand for investment credit to soar, and the accommodation by the state banks of this demand enabled inflation in 1985-1989 to reach levels not seen since 1949. ${ }^{11}$ It was therefore natural that the general public linked the large illegal profits of the dual-pricing system with the high inflation and perceived the inflation to

${ }^{11}$ Fan and Woo (1996) discuss this systemic proclivity toward high inflation. 
be the result of price gouging by corrupt officials. This general perception brought public unhappiness with the corruption to new heights, which led to demonstrations against corruption and inflation in quite a number of large cities at the end of 1985 and 1986.

To address this social unrest, $\mathrm{Hu}$ Yaobang, then head of the Communist Party of China (CPC), started arresting corrupt officials, and the sons of several top conservative leaders were apprehended. This crackdown was interpreted by some conservative leaders as an excuse by the liberal faction to depose them, and this intensified the opposition to the continued leadership of $\mathrm{Hu}$ Yaobang on the grounds of administrative incompetence (look at the high inflation) and ideological revisionism (look at his introduction of material incentives). By aggravating the infighting inside the ruling coalition, the plan track contributed to the dismissal of Hu Yaobang as general secretary of the CPC in January 1987.

It is worthwhile to quote two accounts of this matter at length. According to Baum (1994, pp. 176-177):

... [In 1986] Hu Yaobang raised the ire of Hu Qiaomu [Politburo member] by proposing to formally charge the latter's son, Hu Shiying, with criminal corruption ... [The] incident provoked an immediate reaction among powerful party elders ... a campaign to oust $\mathrm{Hu}$ Yaobang quickly took shape. At the same time, Hu Qiaomu reportedly threw himself at Deng Xiaoping's mercy, tearfully imploring the paramount leader to show mercy toward his errant offspring ...

The highest level gaogan zidi [offspring of a high-ranking cadre] to be judicially punished was the daughter of General Ye Fei, the former commander of the Chinese Navy ... In 1982 the general ... had sharply criticized Hu Yaobang for failing to halt the spread of bourgeois liberalization.

Other gaogan zidi who came under criminal investigation in this period included the prodigal offspring of conservative party elders Peng Zhen and Wang Zhen [both Politburo members]. Like Ye Fei and Hu Qiaomu, Peng and Wang had been vocal critics of bourgeois liberalization, and the raising of allegations of corruption against their children thus carried a strong hint of political retaliation.

According to Fewsmith (1994, p. 177):

In January 1986, Hu Yaobang presided over a huge rally of 8,000 cadres ... called to address the issue of corruption ... A special committee headed by $\mathrm{Hu}$ Yaobang's associate Qiao Shi was established within the Central Committee to root out corruption. In February, ... three sons of high-level cadres were executed. There were soon reports that the children of a number of conservative party leaders, including Peng Zhen, Hu Qiaomu, and Ye Fei, were under investigation, suggesting that $\mathrm{Hu}$ Yaobang was targeting his critics. Moreover, the decision to set up a special committee within the Central Committee to tackle this issue appeared to be a challenge to the CDIC [Central Discipline Inspection Commission], headed by Chen Yun [leader of the conservative faction], as the agency of discipline within the party.

Deng Xiaoping's solution to the growing unrest within society and within the ruling coalition was not to arrest the profiteers but to end the DTPS that fostered such conflicts within the ruling coalition as a byproduct. This is why, in the middle of unprecedented (since 1949) inflation, in May 1988, Deng Xiaoping publicly urged that comprehensive price reform be finished within 
3-5 years. The memorable slogan for this campaign was zhuang jiage guan (crash through the price obstacle).

The reality was that the working of the DTPS generated great social pressures to punish the profiteers but such acts threatened the viability of the ruling coalition. The choice facing the CPC elite was to either maintain the political coalition or maintain the DTPS. For the Chinese politicians, the choice was a no-brainer. This is why price liberalization was brought to virtual completion in the 1990-1991 period even though this was the time that the pro-plan conservative faction had the upper hand in policymaking (in the aftermath of the June 1989 Tiananmen incident). Political reality is the reason why the plan track was reduced steadily even though this act was not Pareto-improving and even though this contradicted the ideological position of the conservative faction.

\section{China's SOE reform: succeeding where others have failed?}

After the 1993 identification by the CPC that "ambiguity in property rights" had been a major factor behind the inefficiency of the SOE sector, significant privatization of small and medium SOEs have occurred in a number of provinces. The notion that SOEs are generally unreformable and hence needed to be privatized has been, and still is, ${ }^{12}$ an issue of great debate among China analysts, as exemplified by the exchange between Jefferson, Rawski, and Zheng (1994) and Woo, Fan, Hai, and Jin (1994) over Woo, Fan, Hai, and Jin's (1993) rejection of Jefferson, Rawski, and Zheng's (1992) finding of positive total factor productivity (TFP) growth in the SOE sector.

The Woo et al.- Jefferson et al. debate started with the observation in Woo et al. (1993) and Woo, Hai, Jin, and Fan (1994) that the estimated deflators for value added in Groves, Hong, McMillan, and Naughton (1994, 1995) and Jefferson et al. (1992), three studies that found large positive TFP growth in the 1980-1989 period, declined secularly over their sample periods when the consumer price index (CPI) rose steadily. Such opposite trends between the CPI and the value-added deflators (VAD) created by Jefferson et al.'s and Groves et al.'s deflation methods is troubling because such occurrences are internationally unprecedented.

Woo, Hai, et al. pointed out that the condition for a secularly declining VAD is given by:

$$
\left[\left(P_{t}^{\mathrm{G}}-P_{0}^{\mathrm{G}}\right) / P_{0}^{\mathrm{G}}\right]<\left[P_{0}^{\mathrm{I}} M_{t} / P_{0}^{\mathrm{G}} Q_{t}\right] *\left[\left(P_{t}^{\mathrm{I}}-P_{0}^{\mathrm{I}}\right) / P_{0}^{\mathrm{I}}\right]
$$

where: $M_{t}=$ intermediate inputs in period $t$ in physical units; $Q_{t}=$ gross output in period $t$ in physical units; $P_{t}^{\mathrm{G}}=$ price of gross output in period $t$, (with $t=0$ the base period); and $P_{t}^{\mathrm{I}}=$ price of intermediate input in period $t .^{13}$

\footnotetext{
${ }^{12}$ Recently, Nolan and Wang (1999) offered a positive assessment, while Chen (1998) offered a negative assessment.

${ }^{13}$ The legacy of central planning is that at the beginning of industrial reform, prices of intermediate inputs to industry were artificially suppressed and prices of industrial goods artificially raised in order to concentrate revenue in the industrial sector to make revenue collection convenient for the state. So, we expect $\left[P_{0}{ }^{\mathrm{I}} M_{t} / P_{0}{ }^{\mathrm{G}} Q_{t}\right]$ to be much smaller than unity.
} 
Table 3

Ratio of GVA/GVO (\%) in 1987 (data supplied by Ren Ruoen)

\begin{tabular}{|c|c|c|c|c|}
\hline \multirow[b]{2}{*}{ Source of data } & \multicolumn{3}{|c|}{$\begin{array}{l}\text { Chinese ratios calculated from different data sources } \\
\text { and under different concepts }\end{array}$} & \multirow{2}{*}{$\begin{array}{l}\text { US ratio } \\
\text { US }\end{array}$} \\
\hline & $\begin{array}{l}\text { Industrial } \\
\text { Yearbook }\end{array}$ & $\begin{array}{l}\text { Input-Output } \\
\text { Table }\end{array}$ & & \\
\hline $\begin{array}{l}\text { Method } \\
\text { of calculating GVA }\end{array}$ & $\begin{array}{l}\text { (1) Not } \\
\text { really known }\end{array}$ & $\begin{array}{l}\text { (2) National } \\
\text { account concept }\end{array}$ & $\begin{array}{l}\text { (3) US Census } \\
\text { concept }\end{array}$ & $\begin{array}{l}\text { (4) US } \\
\text { Census } \\
\text { concept }\end{array}$ \\
\hline Food manufacturing & 13.48 & 14.94 & 27.63 & 32.85 \\
\hline Beverages & 25.02 & 33.55 & 45.62 & 44.61 \\
\hline Tobacco products & 5.46 & 67.10 & 73.37 & 64.27 \\
\hline Textile mill products & 19.21 & 25.63 & 35.51 & 38.84 \\
\hline Wearing apparel & 26.51 & 29.40 & 38.81 & 48.65 \\
\hline $\begin{array}{l}\text { Leather products } \\
\text { and footwear }\end{array}$ & 24.19 & 27.37 & 38.97 & 47.94 \\
\hline $\begin{array}{l}\text { Wood products, } \\
\text { furniture, and fixtures }\end{array}$ & 26.62 & 31.84 & 40.75 & 43.92 \\
\hline $\begin{array}{l}\text { Paper products, printing, } \\
\text { and publishing }\end{array}$ & 28.29 & 32.19 & 41.14 & 55.28 \\
\hline $\begin{array}{l}\text { Chemicals products } \\
\text { (including oil refining) }\end{array}$ & 27.17 & 35.11 & 51.06 & 29.85 \\
\hline Rubber and plastic products & 25.55 & 29.34 & 38.37 & 50.06 \\
\hline Nonmetallic mineral products & 40.37 & 40.98 & 49.06 & 52.40 \\
\hline $\begin{array}{l}\text { Basic and fabricated } \\
\text { metal products }\end{array}$ & 27.05 & 32.36 & 39.86 & 42.94 \\
\hline $\begin{array}{l}\text { Machinery and } \\
\text { transport equipment }\end{array}$ & 33.39 & 34.00 & 42.53 & 44.79 \\
\hline $\begin{array}{l}\text { Electrical machinery } \\
\text { and equipment }\end{array}$ & 29.08 & 29.03 & 37.86 & 55.33 \\
\hline $\begin{array}{l}\text { Other manufacturing } \\
\text { industries }\end{array}$ & 33.20 & 37.11 & 46.00 & 62.78 \\
\hline \multirow{2}{*}{$\begin{array}{l}\text { Total manufacturing } \\
\text { industries }\end{array}$} & 26.49 & 31.43 & 41.62 & 43.86 \\
\hline & \multicolumn{4}{|c|}{ Total manufacturing industries } \\
\hline China, 1980 & 32.7 & & & \\
\hline China, 1984 & 31.4 & & & \\
\hline China, 1988 & 28.5 & & & \\
\hline China, 1992 & 25.4 & & & \\
\hline US, 1989 & 46.2 & & & \\
\hline
\end{tabular}

GVA/GVO from Jefferson et al.'s (1996) data on China is from the Industrial Census.

Alternatively, the condition for a declining VAD can be rewritten as:

$$
\left[\left(P_{t}^{\mathrm{G}}-P_{0}^{\mathrm{G}}\right) / P_{0}^{\mathrm{G}}\right]<\left[1-\left(\mathrm{GVA}_{0} / \mathrm{GOV}_{0}\right)\right] *\left[\left(P_{t}^{\mathrm{I}}-P_{0}^{\mathrm{I}}\right) / P_{0}^{\mathrm{I}}\right]
$$

where: $\mathrm{GVA}_{0}=$ gross value added in time $t$ measured in base prices; $\mathrm{GOV}_{0}=$ gross output value in time $t$ measured in base prices. 
Woo, Hai et al. suggested that the high TFP growth in Groves et al. $(1994,1995)$ and Jefferson et al. (1992) and the declining VAD were the joint results of underdeflating gross output and overdeflating intermediate inputs. This suggestion implicitly assumed that China's production structure $\mathrm{GVA}_{0} / \mathrm{GOV}_{0}$ was similar to that in other economies in order to produce positive comovements between VAD and CPI.

Jefferson, Rawski, and Zheng (1996) rejected Woo, Hai et al.'s suggestion of incorrect deflation and attributed the declining VAD to China's industrial structure differing significantly from those in the advanced market economies. The alleged Chinese economic exceptionalism is that China's manufacturing sector had an usually low GVA/GVO ratio, and they computed it to be $46 \%$ for the US, $40 \%$ for Japan, $45 \%$ for West Germany, and $44 \%$ for the United Kingdom compared to the GVA/GOV ratio for China, which was 33\% in 1980, $31 \%$ in $1984,29 \%$ in 1988 , and $25 \%$ in 1992 .

We identify two difficulties with Jefferson et al.'s (1996) defense. The first difficulty is that the definition of the official Chinese value added data used by Jefferson et al. may be different from the definition of value added used in the advanced market economies. Specifically, there are two commonly used definitions of value added in China, one excludes some payments to intermediate factors and the other definition includes them. We will call them GVA-1 and GVA-2, respectively. GVA-2 matches the way that the US Census calculates GVA, and the US GVA/GOV ratio cited by Jefferson et al. had the GVA calculated as GVA-2. Now, if the official ratios for China reported in Jefferson et al. were constructed using GVA-1, then it is not surprising that GVA/GOV is so low in China compared to the US, but then this would be a comparison of apples and oranges.

The second difficulty with Jefferson et al.'s finding of an unusual industrial structure for China, even if their value-added data were constructed with the second Chinese definition, is that this is a very fragile finding and not a definitive finding. Jefferson et al.'s proposition, which is based on Industrial Yearbook data, does not hold when the 1987 Input-Output Table data are used instead. The Industrial Yearbook data are based on the financial reports (similar to information given to the industrial census) filed by the enterprises, while the Input-Output Table data adjusted the industrial census data to be compatible with economy-wide inputoutput flows.

Table 3 reports the GVA/GOV ratio for different sectors calculated from different sources and according to different definitions of GVA. Column 1 reports the ratio as reported in the 1987 Industrial Yearbook (Jefferson et al.'s data source). The ratios in Columns 2 and 3 are calculated from the Input-Output Table. Column 2 is calculated using GVA-1 (i.e., using the Chinese national account method), and Column 3 is calculated using GVA-2 (i.e., using the US Census method). ${ }^{14}$ The 1987 GVA/GOV ratio for the Chinese industrial sector was $26.5 \%$ according to the Industrial Yearbook, 31.4\% according to the Chinese national account method, and $42 \%$ according to the US Census method. The 1987 ratio for the US using the US Census method was 44\%. Table 3 also shows that each of China's industrial sectoral GVA/GOV ratios calculated according to the US Census method was not only larger than the

\footnotetext{
${ }^{14}$ Ren Ruoen (private communications) calculated Columns 2 and 3 of Table 3.
} 
GVA/GOV ratios from the Industrial Yearbook but also closer to the US sectoral GVA/GOV ratios. When we know that the Chinese and US GVAs are calculated in the same way, there are no great differences between the industrial structures of the two countries.

Jefferson et al.'s finding of low and secularly declining GVA/GOV ratio for China suggests to us undermeasurement of GVA caused by the growing appropriation of capital income by SOE personnel. Fan and Woo (1996) have shown that one unintended result of granting increasing operational autonomy to the SOE managers is that they have, over time, learned how to use various accounting subterfuges to overstate production costs in order to transfer enterprise income to themselves and the workers. This is why GVA/GOV calculated from the financial information supplied by the enterprises has been declining steadily in the reform period and why the adjustment of GVA, to be compatible with economy-wide flows, produced much higher GVA/GOV. This also explains why China's SOEs have been running greater losses every year, even in years of high growth and in sectors where entry by nonstate enterprises has been minimal. ${ }^{15}$

In our opinion, this steady stripping of state assets may subvert political legitimacy much more than a transparent method of privatization would. The increasing public outrage over the inequity of the informal privatization of the SOE sector is well captured in a recent book by He Qinglian who wrote that the SOE reform has amounted to:

a process in which power-holders and their hangers-on plundered public wealth. The primary target of their plunder was state property that had been accumulated from forty years of the people's sweat, and their primary mean of plunder was political power. ${ }^{16}$

Just like their compatriots in EEFSU, Chinese SOE managers focus more on the looting of their firms than on improving their operations. In a study of SOEs in Chongqing, Chen (1998) reported:

Municipal officials often find that factory directors appointed to money-losing firms do well and bring the firms out of the red in the first two years, and then start to take part in graft, embezzlement, bribery and, most frequently, pirating state assets.

For practical purposes, the TFP debate is over. There is now no doubt about which side of the debate the Chinese government has come out on. Premier Zhu Rongji declared back in 1996, right after 4 years of double-digit economic growth, that:

The current problems of SOEs are excessive investments in fixed assets with very low return rates, resulting in the sinking of large amounts of capital; low sales-to-production ratio giving

15 Jefferson et al. (1994, p. 240) criticized Woo et al. (1993) for using a survey of urban residents to calculate the indirect income of SOE workers because the data included "earning from second jobs, royalties, lecture fees, and transfer payments." What Woo, Fan, et al. (1994) did not mention in their reply was that this criticism was invalid because Jefferson et al. thought that Woo et al. were using Table 8 in Zhao (1992) when Woo et al. were actually using Table 9, which was based on the bank records of SOE transactions and hence did not contain information on the "typical" worker's income from royalties and lecture fees.

${ }^{16}$ He Qinglian, Zhongguo de Xianjing, (China's Pitfall), Mingjing Chubanshe, Hong Kong. The translated quote is from Liu Binyan and Perry Link, "China: The Great Backward?" The New York Review of Books, October 8, 1998, p. 19. 
rise to mounting inventories. The end result is that the state has to inject an increasing amount of working capital through the banking sector into the state enterprises. ${ }^{17}$

The announcement at the 15th CPC Congress in September 1997 that there would be a determined effort to greatly diversify the ownership structure was the logical outcome of the above official verdict on the performance of the SOE sector and of official concern about the political repercussions of the accelerating process of spontaneous privatization.

\subsection{Facing the perils of privatization, Chinese-style}

There are two analytical divides in describing the wide array of privatization practices. The first divide is between individual sales and mass privatization, ${ }^{18}$ and the second divide is between insider privatization and outsider privatization. These two divides are not mutually exclusive. Management and employee buy-outs are insider privatizations and direct sales to third parties are outsider privatizations. Voucher privatizations with generous concessions to employees of the SOEs are insider privatizations (e.g., Russia), and voucher privatizations conducted on a level playing field (e.g., the Czech Republic) are outsider privatizations. For some transition economies, mass privatization had appeared attractive because individual sales, in the absence of developed capital markets, would have taken too long and the perverse incentives facing the SOEs awaiting privatization would have generated management problems beyond the governments' ability to handle.

The experiences with mass privatization in EEFSU show that the task is an extremely difficult one and that the outcomes have consistently fallen below initial expectations. For example, in Russia, the "loans-for-shares" privatization transferred the country's enormous mineral wealth to a group of oligarchs, and the weak administrative and legal structures allowed many managers to take effective control of the privatized firms and loot them instead of improving their operations. In the judgment of Frydman, Murphy, and Rapaczynski (1998), despite the diverse privatization methods, the outcome in most cases in the majority of the countries (especially in FSU) is that control of the firms went to some form of manager-labor coalition, producing what they aptly described as "capitalism with a comrade face." Privatization has certainly not unleashed massive productivity increases.

Furthermore, the EEFSU experiences warn that mass privatization is an exceedingly dangerous business politically, no matter how it is done, be it outsider privatization or insider privatization. This is because the mass privatization of SOEs generates so much rent that corruption is impossible to avoid, and the resulting corruption inevitably delegitimises the government. Corruption leading to political demise appears to be an inevitable byproduct of mass privatization, e.g., Vaclav Klaus in the Czech Republic and Anatoli Chubais in Russia.

Most scholars of enterprise restructuring would now agree that privatization is a necessary, but not sufficient, condition for improved enterprise performance. The emergence of a

\footnotetext{
17 "Guo you qiye sheng hua gaige ke burong huan," (No time shall be lost in further reforming SOEs), speech at the fourth meeting of the Eighth People's Congress, People's Daily, Overseas Edition, March 11, 1996.

18 Mass privatization of course does not mean unloading all the SOEs at once, it means selling a large block of the SOE sector in each session.
} 
dynamic privately owned industrial sector from the old SOE sector requires the existence of hard budget constraints, competition, and legal (e.g., bankruptcy courts) and commercial (e.g., accounting standards) institutions that work properly. Since China, like most transition economies, has either inchoate or inexperienced administrative, legal, and economic institutions, does this mean that it should not have began privatization, least of all, to have accelerated the pace of it recently?

We see two reasons for why the nonstellar outcomes in EEFSU have not discouraged China from moving ahead with privatization. The first reason comes from Nellis (1999) who points out that "governments that botch privatization are equally likely to botch the management of state-owned firms." The answer is not to avoid privatizations but to implement more careful privatizations: governments in transition economies should "push ahead, more slowly, with case-by-case and tender privatizations, in cooperation with the international assistance community, in hopes of producing some success stories that will lead by example."

The second reason lies in that the delay of privatization can be costly to the government politically. Stealing by managers does occur during privatization and creates a social backlash against the government, but the maintenance of the status quo has become increasingly difficult because SOE managers in China know from the EEFSU experience that they are in an endgame situation. The widespread spontaneous privatization by SOE managers could create the same social unrest that would topple the regime.

China has so far avoided widespread organized public dissatisfaction with its partial privatization of the small and medium state enterprises. The central government has given itself an indirect role in the privatization process in order to avoid bearing the brunt of any negative fallout. It works by the central government passing to the local governments the financial responsibility for most of the state enterprises located in their areas. In the case of loss-making enterprises, the local government is forced to either come up with a subsidy or privatize them. The second option has been the common choice. The local party secretary who gets rid of the loss-makers without arousing local resentment is promoted. But, if there is substantial public resentment over the privatization, then the party secretary is reprimanded or replaced for inept implementation of state policy.

The question is whether this strategy can continue to shelter the central government from the public backlash over "inept" privatization, especially when the large state enterprises are privatized. The road to a prototype WTO market is a perilous one for China's policymakers, but it is an unavoidable journey if China is to continue moving up the value-added ladder and become a modern market economy.

\section{Fiscal contracting: the newest lesson from China to Russia?}

A number of China scholars have observed that local governments in China have been a primary force for economic development. This phenomenon has been called "developmental localism" by Zheng (1994), "local corporatism" by Oi (1992), and "market-preserving federalism" by Montinola, Qian, and Weingast (1995). The pro-growth policies of China's local governments stand in sharp contrast with the "status quo" policies of Russia's local 
governments. According to a comprehensive analysis of 10 sectors of the Russian economy in 1999, the McKinsey Global Institute (1999) found that:

In nine of the ten sectors, the direct cause of the low economic performance is market distortions that prevent equal competition. The distortions come from attempts to address social concerns, corrupt practices, and lack of information.

In the manufacturing sectors, regional governments channel implicit federal subsidies to unproductive companies. Such subsidies take the form of lower energy payments and are allegedly intended to prevent companies from shutting down and laying off employees. This puts potentially productive companies at a cost disadvantage, blocking investments and growth on their part.

In the service sectors, where employment should grow, investments by efficient companies are discouraged by the presence of well connected unproductive incumbents who benefit from favorable regulations, weak law enforcement, and privileged access to land or government procurements.

Furthermore, these sector level market distortions are key contributors to macroeconomic instability, because they reduce government revenues and increase its expenditures. Macroeconomic instability itself is another important deterrent to investments.

We found the other often mentioned reasons for Russia's economic problems to play a much smaller role (e.g. poor corporate governance and lack of a transport infrastructure).

The prevailing opinion among China scholars is that the enthusiasm of China's local government's for economic development came from post-1978 changes in the fiscal relationship between the central and local governments that allowed the latter to keep a greater proportion of the taxes that it collected for the central government. The extreme examples of fiscal decentralization were Guangdong and Fujian who, for long periods in the 1980s, paid fixed lump sum taxes and kept all tax revenue above the quota, i.e., a marginal retention rate (MRR) of $100 \%$.

Jin, Qian, and Weingast (1999) found in cross-provincial regressions that MRR was positively linked with employment growth in nonstate enterprises and with the degree of SOE restructuring during the 1982-1992 period. They claimed that the absence of Chinese-style fiscal contracting (market-preserving federalism) in Russia is the reason for the "status quo" policies of Russia's local governments. Is this the real lesson from China for Russia in the wake of earlier lessons that turned out to be inapplicable? ${ }^{19}$

In the judgment of Blanchard and Shleifer (2000), Chinese-style federalism cannot work in Russia because Russia is now a democratic state and no longer a Leninist state like China. To see their argument, suppose that the local government in a transition economy faces the following two policy choices:

- Policy X that requires the local government to prey on private businesses to pay for its expenditure and support the local SOEs that employ a significant proportion of the local work force; and

\footnotetext{
${ }^{19}$ See Woo (1994) for a discussion of some of the commonly claimed "lessons from China" for Russia and Eastern Europe.
} 
- Policy Y that requires the local government to reduce protection and subsidies to local SOEs (in order to force them to increase efficiency by laying off workers) and to foster growth of new private enterprises by cutting taxes and fees (an action made affordable by the cuts in SOE subsidies).

Now assume the following consequences:

- Policy X yields direct benefits to the local government worth $b_{\mathrm{X}}$, and the probability $p_{\mathrm{X}}$ that the local government will stay in power.

- Policy Y yields direct benefits worth $b_{\mathrm{Y}}$, which is a positive function of MRR, and the probability $p_{\mathrm{Y}}$ that the local government will stay in power.

Obviously, Policy Y will be enacted only if

$$
p_{\mathrm{Y}} b_{\mathrm{Y}}>p_{\mathrm{X}} b_{\mathrm{X}}
$$

or

$$
p b_{\mathrm{Y}}>b_{\mathrm{X}}
$$

where $p=\left(p_{\mathrm{Y}} / p_{\mathrm{X}}\right)$.

In a Leninist state, $p$ is a policy variable because the central government appoints the local governor, which is the situation in China. So, if the central government wishes Policy $Y$ to be chosen, it just sets $p_{\mathrm{X}}=0$ (as long as $b_{\mathrm{Y}}$ is positive). Ceteris paribus, an increase in MRR increases $b_{\mathrm{Y}}$ and hence the probability that Policy $\mathrm{Y}$ will be chosen by the governor, but the level of the MRR is really just "icing on the cake" for a local governor in a Leninist state.

Whereas in a town in a democratic country where the local SOEs employ a large proportion of the workforce, $p_{\mathrm{Y}}$ may well be sufficiently close to zero such that jacking up MRR tremendously by the central government will not be enough to induce the local government to choose Policy Y.

It is interesting to note that in a country where the central government is committed to maximizing GDP growth, the relationship between MRR and the provincial growth rate may be one where causality runs both ways. The minimisation of revenue losses from the use of MRR to promote the overall GDP growth rate would lead the central government to extend lower MRRs to provinces that have higher growth potential. The higher MRRs given to the southeastern coastal provinces of Guangdong and Fujian could well have been based on this consideration.

The key regressions in Jin et al. are essentially growth equations because the growth rates of provincial employment in the nonstate, nonagricultural sector are highly correlated with the growth rates of provincial GDP. The Jin et al.'s regressions do not contain any of the usual independent variables found in Barro-type growth equations, however. Chen (2001) added MRR and other proxies for fiscal decentralization into Barro-type provincial growth regressions and found all of them to have significant negative coefficients over the 19791993 period. Chen also cited two studies by Justine Lin that found contradictory results about the impact of fiscal decentralization on economic growth. All of these suggest that the 
empirical case for the effectiveness of fiscal contracting in promoting provincial growth is a fragile one and that more research is needed.

A priori, the relationship between MRR and the growth rate in China could well be a Laffer-type curve. In some provinces, the larger amount of retained revenue could have resulted in more white elephant projects or larger subsidies to inefficient large SOEs that were deemed too big to fail. The negative coefficient for MRR in Chen's (2001) growth regressions is a warning that China might well have exceeded the optimal value of MRR by the end of the 1980 s.

We are of course not denying either that the 1982-1993 system of "tax farming" was better than the pre-1979 tax system or that it stimulated the appetites of some local governments for economic development. Our point is just that China deserved a better tax system than the 1982-1993 tax system of annual negotiations with individual provinces, a system that created extraordinary microeconomic distortions and a fiscal crisis for the central government to boot. ${ }^{20}$ These flaws explain why China replaced fiscal contracting in January 1994 with a tax system that has the value-added tax (VAT) as its centerpiece. The 1983-1993 Chinese tax system extolled in Jin et al. was similar to the tax farming system of medieval Europe, and the post-1993 Chinese tax system (at least on paper and in intentions) is similar to the tax systems of modern Europe. The right lesson for fiscal reform in Russia ${ }^{21}$ is the same lesson that China has learned over the last two decades, which is to allow its fiscal system to converge to those of the advanced WTO members.

\section{Gorbachev's application of Chinese-style reforms: two lessons from Russia to China}

It would be historically inaccurate to assume that market reforms in Russia started only in 1992 with the Boris Yeltsin government. The gross inefficiency of the Soviet economy and its slide into technological stagnation during the nomenklatura communism of Leonid Brezhnez in the 1970s had fermented much reformist thinking among Soviet economists. By the time Mikhail Gorbachev assumed political power in May 1985, there were already many established influential economists urging market-oriented reforms, e.g., Boris Kurashvili argued for Hungarian-style market socialism and Oleg Bogomolov for Chinese-style incremental liberalization.

Gorbachev was not a quick convert to market reforms, however. The first 2 years of his rule were spent trying to propel the economy out of its doldrums by accelerating the technological level of Soviet industries through large investments in the machine tool industry. The acceleration strategy failed, leading Gorbachev to seek "radical reforms" of the economy. The influence of China's reform strategy is clearly seen in Gorbachev's

\footnotetext{
${ }^{20}$ Tsai (2000) has suggested that "market-thwarting federalism" might be a more accurate description of this system. See also Wong (1991) and Wong, Heady, and Woo (1995).

${ }^{21}$ Medieval-style tax farming is still inappropriate for the present Russian economic situation even if one agrees with the "industrial feudalism" characterisation of it by Ericson (1999a).
} 
arguments in August 1987 "in favor of family contract, family teams, and . . leasehold" 22 to be introduced in Soviet agriculture. Gorbachev's radical reform program was unveiled in June 1987 at the Soviet economic plenum, which passed the Law on State Enterprises and Basic Provisions for Fundamental Perestroika of Economic Management to devolve decisionmaking power from the ministries to the SOEs. Just like in China, Soviet SOEs were given more freedom in their output choices and freedom to enter into long-term contractual agreements for purchases and sales and were allowed to retain part of their profits to use at their discretion, e.g., for technological upgrading and as incentive bonuses. In return, the SOEs were required to do "full economic accounting," the euphemism for SOEs to be responsible for their losses. As in China, deliveries to the state would still be required (state orders), for which subsidized inputs would be made available to the SOEs, but state orders would be reduced over time to cover only $40-60 \%$ of all production. ${ }^{23}$

The explosive growth China's nonstate industrial sector had made a deep impression on the Russian reformers and inspired them to push for a double track on ownership as well. Academician Leonid Abalkin, a prominent leader in reform thinking, predicted in 1986 that the radical reforms of Gorbachev would, within a decade, enable cooperatives to account for $10 \%$ of GDP and private enterprises for $4 \%$ of GDP. ${ }^{24}$ Various decrees had been issued earlier to stimulate the cooperative sector, and they were greatly expanded with the adoption of the Law on Cooperatives in May 1988.

The Law on Cooperatives was categorical in making the formation of cooperatives an easy task: "A cooperative is organized at the desire of citizens, exclusively on a voluntary basis. The creation of a cooperative is not conditional upon any special permission whatsoever by Soviet, economic, or other bodies." 25 There was no ceiling set on the number of members, and there was no limit on the number of nonmembers that could be hired on contract. Furthermore, cooperatives could set their prices according to market conditions. In the words of Yevgenii Yasin, a senior member of the State Commission on Economic Reform:

The 1987 reform was in many ways an attempt to implement the Chinese model in Russia. It envisioned enterprises, and joint ventures would constitute the free sector, existing alongside the state sector, with its mandatory state orders, fixed prices, and centralized allocation of inputs. (Ellman \& Kontorovich, 1998, p. 169)

The Soviet economy started disintegrating from 1989 onward, ${ }^{26}$ however, and, broadly speaking, there are two explanations about the causes: one, Gorbachev's Chinese-style reforms unraveled the Soviet economy, and two, the reforms would have worked if Gorbachev had only tightened repression on his opponents instead of embracing glasnost.

\footnotetext{
22 Aslund (1991, p. 103).

23 Ellman and Kontorovich (1998, p. 103); but, Aslund (1991, p. 127) reported the intended range to be 50-70\%.

24 Aslund (1991, p. 168).

25 Quoted in Aslund (1991, p. 169).

${ }^{26}$ For contemporary accounts, see Central Intelligence Agency and Defense Intelligence Agency (1989, 1990). Malia (1994) gives an excellent analysis of the politics of the period.
} 
The claim that the reforms caused the collapse comes from two related views about the Soviet economy. The first view is that the existing heavy industrial sector was too large for a marketized Soviet economy, as depicted in Fig. 3. This sector had to shrink because its value added at market prices was negative. Ericson's (1999b) careful examination of the changes in Russia's input-output table in 1991-1992 and Berg, Borernsztein, Sahay, and Zettelmeyer's (1999) thorough econometric investigation of EEFSU economies support this value-subtracting view of the Soviet-type industrial sector.

The second view is more general and is based on Kornai's (1992) argument that systemic stability is assured only when the regime in the political sphere is compatible with the regime in the economic sphere. A totalitarian Communist regime that is ideologically committed to the suppression of private ownership requires for its sustenance a centrally planned economy, and vice versa. If the nature of the regime changes in only one sphere, then the stability of the regime in the other sphere will be disturbed, culminating into systemic collapse. This means that unless partial marketization is matched by an appropriate modification in Communist ideology, either the economic reform will be reversed or the existing political regime will be toppled. Hence, in Kornai's framework, the 1987 Chinese-style reforms removed the last vestiges of coherence within the Soviet political economy system and precipitated its collapse.

The counterhypothesis to the views of Ericson and Kornai holds that the Chinese-style reforms would have effected a less costly economic transition for Russia if Gorbachev had only intensified the police state nature of Soviet society instead of lessening it as he did (e.g., Griffin and Khan, 1993). The reasoning is that a systemic transformation necessarily creates losers; firm political control is therefore required to prevent the losers from creating social instability that would disrupt production. This viewpoint was echoed by Yevgenii Yasin:

a gradual transition to a market economy [would have required] ... a less radical and painful departure from socialist ideals. The secret police and censorship would perpetuate the old ideological cocoon, within which a new economic system would be developing like a butterfly ... The last chance was lost in 1989, when Gorbachev's political reform removed the Communist Party from power. Afterwards, events unfolded spontaneously, no longer under the control of the government or the Party. (Ellman \& Kontorovich, 1998, p. 169)

The first serious problem with the view that political liberalization undermines economic liberalization is the limited validity of the assumption that only a totalitarian political regime can maintain adequate law and order in a society going through economic restructuring. The jackboot of military rule could not prevent Ceausescu of Romania and Soeharto of Indonesia from being deposed by their angry populace. Staying in power requires more than the liberal use of the stick. History clearly shows that carrots and compromise can sometimes be even more crucial.

The second serious problem with the necessity-for-brute-force hypotheses is that it ignores the fact that the bludgeoning cannot be confined just to laid-off state workers on strike, substantial amounts of it would also have to be directed at members of the Communist elite. This is because many Soviet officials who stood to lose their supervisory power over the SOEs had joined the Communist ideologues in sabotaging the implementation of the 
reforms. ${ }^{27}$ Would the Communist Party of the Soviet Union have accepted Stalin-style purges by Gorbachev in his de-Stalinization of the economy? A positive answer is highly debatable because of the seemingly ironclad self-protective consensus of "live and let live" among the post-Stalin Communist elite.

In trying to assess the relative merits of the two broad explanations for the disintegration of the Soviet economy, it is instructive to note how Gorbachev reacted to the failure of his Chinese-style reforms. He first replaced democratic centralism with open popular elections and then authorized Academician Stanislav Shatalin to draft a plan that would transform the planned economy to a market economy in 500 days. ${ }^{28}$ These actions suggest that Gorbachev had concluded that the biggest obstacle to the development of a market economy was the Communist Party itself and that gradual reforms could not work in the Soviet Union.

Of the many interesting lessons for China from Gorbachev's unsuccessful Chinese-style reforms, we single out two that concern the viability of continued deepening of economic reform and opening. The first lesson derives from the fundamental message in Kornai's (1992) analysis that true systemic stability requires that the political regime be compatible with the economic regime. Sustained economic prosperity requires a market economy that is integrated into the international economy, and a true market economy requires (constitutionally protected) private ownership to be its institutional norm. The lesson for China from Russia is that the avoidance of economic disruptions from political upheavals lies in the willingness and ability of the ruling elite to make adroit changes to the nature of the political regime to accompany the changes in the economic regime. Seen in this light, China's aggressive push for WTO membership, the recent revision of China's constitution to give private property the same legal status as public property, and the reduction of the central bureaucracy by over a third since 1995 are signs of farsightedness in the third generation of Chinese leaders.

The second lesson for China from Gorbachev's reforms derives from the fact that the primary political opposition to marketization came from within the Party and that the primary resistance to implementation of reforms came from within the government. Because the policy dissent and implementation sabotage are of the in-house variety, purges could destroy the internal unity required for the political survival of the ruling elite and for maintaining stable center-provincial political arrangements. The second lesson is that the fourth generation of Chinese leaders will have to come up with creative mechanisms to offset the natural proclivity of loyal party incumbents to favor the status quo over additional institutional reforms.

\section{Conclusion}

The desirability of WTO membership for China depends on whether its economic successes to date are the result of its discovery of new institutional forms (e.g., dual-track

\footnotetext{
${ }^{27}$ See accounts by Vladimir Mozhin and Vadim Medvedev in Ellman and Kontorovich (1988, pp. 151-154).

${ }^{28}$ For details, see Yavlinsky et al. (1990).
} 
pricing, SOE contracts, and fiscal contracts) that are optimal for China's particular economic circumstances or are the result of the convergence of its economic institutions to those of a typical advanced member of WTO. If the experimentalist interpretation is correct, then the institutional harmonization required by WTO may blunt future growth. Also, if the convergence explanation is true, then WTO membership will help future growth.

Our dismissal of some recent claims of Chinese economic exceptionalism can be summarized as follows. The data do not support the general equilibrium effects of the DTPS as predicted by the "gain without pain" analysis of Lau et al. (2000). The serious flaw of the DTPS that has been downplayed in their paper was the widespread corruption that it spawned and the political disunity that the corruption created. It was because of the economic and political unsustainability of the DTPS that it was replaced by complete price liberalization in 1990-1991, despite the fact that this was not a Pareto-improving change.

Jefferson et al. (1996) defended their finding of a significant positive TFP growth rate from charges of implausibility by claiming that China's industrial structure was markedly different from those of the advanced capitalist economies. Their claim does not hold when the industrial structure is calculated from input-output data. In a way, the recent acceleration of privatization in China definitively settles the argument of whose estimation results are more plausible. Since the EEFSU experience shows that privatization can be politically dangerous for the government implementing it, this new direction in SOE reform will require unusually skillful political management by the Chinese leadership.

The fiscal decentralization that took the form of province-specific tax contracts rendered the revenue of the local governments more dependent on the local level of economic development and hence induced many of them to promote local growth. The negative byproducts of the tax contracts were local protectionism, industrial duplication, and a great reduction in the ability of the central government to undertake pressing infrastructure investments and poverty alleviation projects. Finally, the empirical validity of the positive growth impact of fiscal decentralization, after the influences of other variables are controlled for, is still an open question.

The uniform tax system introduced in 1994, which is similar to the tax systems of the advanced members of the WTO, is a definite improvement over its predecessor. So, if there is any lesson for Russia to learn from China's fiscal decentralization, as claimed by Jin et al. (1999), it should be based on the present tax system and not on the pre-1994 tax system. In any case, as pointed out by Blanchard and Shleifer (2000), it is unlikely that the kind of decentralized tax system designed for a politically centralized country will produce the same outcomes when applied to a politically decentralized country.

The failure of Gorbachev's 1987 reforms suggests, first, the limited applicability of China's double-track transition strategy of EEFSU economies and, second, that the greatest challenge to the deepening of economic reform and opening may come from the entrenched interest within the ruling structure. China's forthcoming WTO accession could be seen as an attempt by reformers to lock economic policies on to a course for further marketization and internationalization that is costly to reverse. 


\section{Acknowledgments}

I thank the participants of the conferences and seminars at Herriot-Watt University, Australian National University, Middlesex University, Victoria University of Wellington, Otago University, University of Auckland, and University of Hong Kong for very helpful discussions on the issues analysed here. I am particularly indebted to Mark Schaffer. Tomasz Mickiewicz, Dwight Perkins, Jeffrey Sachs, Ren Ruoen, Liu Shaojia, Huang Yiping, Hai Wen, Fan Gang, and Andrew Berg for sharing many of their insights with me and to Deng Haiyan for excellent research assistance. Ren Ruoen deserves a special acknowledgement of gratitude for alerting me to the more accurate input-output data for calculating the structure of China's industrial sector. This paper is part of the "Property Rights and China's Enterprise Reform” project (HKU7167/98H) supported by the Research Grant Council of Hong Kong.

\section{References}

Aslund, A. (1991). Gorbachev's struggle for economic reform. London: Pinter Publishers (updated and expanded edition).

Baum, R. (1994). Burying Mao: Chinese politics in the age of Deng Xiaoping. Princeton.

Berg, A., Borensztein, E., Sahay, R., \& Zettelmeyer, J. (1999). The evolution of output in transition economies: explaining the differences. International Monetary Fund, WP/99/73.

Blanchard, O., \& Kremer, M. (1997). Disorganization. Quarterly Journal of Economics, 112 (4), 1091-1126 (November).

Blanchard, O., \& Shleifer, A. (2000). Federalism with and without political centralization: China versus Russia. Massachusetts Institute of Technology, manuscript (October).

Central Intelligence Agency and the Defense Intelligence Agency (1989). The Soviet Economy in 1988: Gorbachev changes course. Report to the Subcommittee on National Security Economics, Joint Economic Committee, Congress of the United States.

Central Intelligence Agency and the Defense Intelligence Agency (1990). The Soviet Economy stumbles badly in 1989. Report to the Technology and National Security Subcommittee, Joint Economic Committee, Congress of the United States.

Chen, A. (1998). Inertia in reforming China's state-owned enterprises: the case of Chongqing. World Development, 26 (3), 479-495 (March).

Chen, Y. (2001). Decentralization, local provision of public goods and economic growth: the case of China. In: R. Garnaut, \& L. Song (Eds.), Sustainability of China's economic growth in the 21st century. Canberra, Australia: Asia Pacific Press.

Chow, G. (1993). Capital formation and capital growth in China. Quarterly Journal of Economics, (August).

Ellman, M., \& Kontorovich, V. (1998). The destruction of the soviet economic system: an insiders' history. Armonk: M. E. Sharpe.

Ericson, E. (1999). The post-Soviet Russian economic system: an industrial feudalism. Columbia University, manuscript.

Ericson, R. (1999). The structural barrier to transition: a note on input-output tables of centrally planned economies. Columbia University, manuscript.

Fan, G., \& Woo, W.T. (1996). State enterprise reform as a source of macroeconomic instability. Asian Economic Journal, (November).

Fewsmith, J. (1994). Dilemmas of reform in China: political conflict and economic debate. M.E. Sharpe.

Frydman, R., Murphy, K., \& Rapaczynski, A. (1998). Capitalism with a comrade's face. Central European Univ. Press. 
Griffin, K., \& Khan, A. R. (1993). The transition to market-guided economies: lessons for Russia and Eastern Europe from the Chinese experience, manuscript.

Groves, T., Hong, Y., McMillan, J., \& Naughton, B. (1994). Autonomy and incentives in Chinese state enterprises. Quarterly Journal of Economics, 109 (1), 185-209 (February).

Groves, T., Hong, Y., McMillan, J., \& Naughton, B. (1995). Productivity growth in Chinese state-run industry. In: F. Dong, C. Lin, \& B. Naughton (Eds.), Reform of China's state-owned enterprises. London: MacMillan.

Jefferson, G., Rawski, T., \& Zheng, Y. (1992). Growth, efficiency, and convergence in China's state and collective industry. Economic Development and Cultural Change, 40 (2), 239-266 (January).

Jefferson, G., Rawski, T., \& Zheng, Y. (1994). Productivity change in Chinese industry: a comment. China Economic Review, 5 (2).

Jefferson, G., Rawski, T., \& Zheng, Y. (1996). Chinese industrial productivity: trends, measurement issues, and recent developments. Journal of Comparative Economics, 23, 146-180.

Jin, H., Qian, Y., \& Weingast, B. (1999). Regional decentralization and fiscal incentives: federalism, Chinese style, manuscript (August).

Kornai, J. (1992). The socialist system: the political economy of communism. Princeton.

Kornai, J. (2000). Ten years after 'the road to a free economy': the author's self-evaluation. Paper presented at the World Bank, Annual Bank Conference on Development Economics (April).

Lau, L. J., Qian, Y., \& Roland, G. (2000). Reform without losers: an interpretation of China's dual-track approach to transition. Journal of Political Economy (February).

Lipton, D., \& Sachs, J. D. (1992). Prospects for Russia's economic reforms. Brookings Papers on Economic Activity, 2, 213-265.

Malia, M. (1994). The Soviet tragedy: a history of socialism in Russia, 1917-1991. New York: Free Press.

McKinsey Global Institute. (1999). Unlocking economic growth in Russia (October).

Montinola, G., Qian, Y., \& Weingast, B. (1995). Federalism, Chinese style: the political basis for economic success in China. World Politics, (October).

Nellis, J. (1999). Time to rethink privatisation in transition economies? International Finance Corporation Discussion Paper No. 38, World Bank.

Nolan, P., \& Wang, X. (1999). Beyond privatization: institutional innovation and growth in China's large stateowned enterprises. World Development, 27 (1), 169-200 (January).

Oi, J. (1992). Fiscal reform and the economic foundations of local state corporation in China. World Politics, 45 (1), 99-126 (October).

Sachs, J. D., \& Woo, W. T. (1994). Structural factors in the economic reforms of China, Eastern Europe, and the Former Soviet Union. Economic Policy, 18, 101-145 (April).

Sachs, J. D., \& Woo, W. T. (2000). Understanding China's economic performance. Journal of Economic Reform, 4 (1), $1-50$.

State Statistical Bureau of China. (1999). Comprehensive statistical data and materials on 50 years of new China. China Statistical Press.

Tsai, K. (2000). Off balance: fiscal federalism and the rise of extra-budgetary and informal finance in China. Paper presented at the 2000 Annual Meeting of the American Political Science Association, Johns Hopkins University, manuscript (August).

Wong, C. P. W. (1991). Central-local relations in an era of fiscal decline: the paradox of fiscal decentralization in post-Mao China. China Quarterly, 691-715 (December).

Wong, C. P. W., Heady, C., \& Woo, W. T. (1995). Fiscal management and economic reform in the People's Republic of China. Oxford Univ. Press.

Woo, W. T. (1994). The art of reforming centrally-planned economics: comparing China, Poland and Russia. Journal of Comparative Economics, 18 (3), 276-308 (June).

Woo, W. T. (1998). Chinese economic growth: sources and prospects (Zhongguo Quan Yaosu Shengchan Lu: Laizi Nongye Bumen Laodongli Zai Pei Zhi de Shouyao Zuoyong). In: M. Fouquin, \& F. Lemoine (Eds.), The Chinese economy (Jingji Yanjiu). (vol. 3). London: Economica. 
Woo, W. T. (2000). Comments on 'reform without losers: an interpretation of China's dual-track approach to transition' by Lau, Qian and Roland, manuscript.

Woo, W. T., Fan, G., Hai, W., \& Jin, Y. (1993). The efficiency and macroeconomic consequences of Chinese enterprise reform. China Economic Review, 4 (2).

Woo, W. T., Fan, G., Hai, W., \& Jin, Y. (1994). Productivity change in Chinese industry: authors' reply. China Economic Review, 5 (2).

Woo, W. T., Hai, W., Jin, Y., \& Fan, G. (1994). How successful has Chinese enterprise reform been? Pitfalls in opposite biases and focus (Zhongguo qiye gaige jiujing huode le duo da chenggong). Journal of Comparative Economics (Jingji Yanjiu), 6 (June).

Yavlinsky, G., Fedorev, B., Shatalin, S., Petrakov, N., Aleksashenko, S., Vavilov, A., Grigoriev, L., Zadornov, M., Machits, V., Mikhailov, A., \& Yasin, E. (1990). 500 days: transition to the market. New York: St. Martin's Press.

Zhao, R. (1992). Special features of China's income distribution during the transition period. Jingji Yanjiu, 1, 53-63.

Zheng, Y. (1994). Quasi-corporatism, developmental localism, and behavioral federalism. PhD dissertation, Princeton University. 